\title{
Impacts of Industrial Effluent on River Kabul
}

Ghazal Nosheen, Muhammad Ullah, Kashif Ahmad Khan and Attiq Ur Rehman

Ghazal Nosheen

Abstract: The disposal of untreated industrial effluent into receiving water courses has become a major environmental challenge being faced by most of the developing countries. The high-strength and toxic wastes are responsible for a variety of water-borne diseases. In Pakistan numerous industrial units that dispose their effluent directly into receiving stream without any treatment. This study was, therefor designed to assess the wastewater characteristics of some major industrial units in the surrounding area of River Kabul, which is one of the most significant resources of water in the north region of the country.

The main objectives of this study were to evaluate the wastewater characteristics of some major industrial units in terms of BOD (Biochemical Oxygen Demand), COD (Chemical Oxygen Demand), and TSS (Total Suspended Solids) etc. For this purpose, various representative samples were collected from the major industrial units like sugar, paper, ghee (Butter) and textile mills, and were analyzed using standard laboratory techniques. The results indicates that the BOD of sugar, paper, ghee (butter) and textile mills is in the range of $2235 \mathrm{mg} / \mathrm{L}$, $1150 \mathrm{mg} / \mathrm{L}, 844 \mathrm{mg} / \mathrm{L}$ and $745 \mathrm{mg} / \mathrm{L}$, respectively. Whereas, the COD of sugar, paper, ghee and textile mills was noticed to be $3945 \mathrm{mg} / \mathrm{L} 2045 \mathrm{mg} / \mathrm{L}, 2240 \mathrm{mg} / \mathrm{L}$ and $1244 \mathrm{mg} / \mathrm{L}$ respectively. Owing to the disposal of such highstrength wastes water without treatment, a remarkable increase in the TSS from 96 to $382 \mathrm{mg} / \mathrm{L}$, and decrease in DO (Dissolved Oxygen) concentration from 8.8 to $6.7 \mathrm{mg} / \mathrm{L}$ of River Kabul was observed.

The results of this study suggest that all the wastewater coming from the industrial sources should be properly treated as an integral part of their production before their final disposal into River Kabul to secure its natural water quality.

Key words: Industrial effluent, wastewater treatment, BOD (Biochemical Oxygen Demand), COD (Chemical Oxygen Demand), TSS (Total Suspended Solids), River Kabul, Pakistan

\section{Introduction}

The fast industrialization and elevated population growth rate are some of the major factors that are adversely disturbing the global environment. Not only is the accessible water quantity declining day by day, but they are being polluted at an alarming rate due to the discharge of untreated domestic and industrial effluent. Unfortunately, the developing countries also lack the potential research, effective legislation, adequate planning, skilled personnel, and awareness required for protecting the environment (Panayotou 1994).

In Pakistan there are several industrial unit that are discharging million gallons of untreated effluent directly into the receiving stream, canals, rivers, etc., due to which the quality of receiving water courses are rapidly being polluted (Pak-EPA 1999). Not only is aquatic life vanishing from these water courses, but they are also losing their aesthetic values. These water courses have become the major sources of a number of water borne diseases like Hepatitis A, Cholera, Typhoid, gastro-intestinal diseases, etc. Every year thousands of people die all over the world, especially in the developing nations, due to such diseases (Steel 1995).
A variety of liquid, gaseous and solid wastes is being generated from industries and disposed directly without any treatment. Some of the main sources of water pollution are paper, textile, tanneries, sugar, ghee (butter) mills, etc. These industrial units not only discharge high strength effluents, but their wastes also contain a significant amount of toxic heavy metals like lead, cadmium, chromium and mercury, and a large quantity of organic solvents like absorbable organic halides, etc (Ali et al 2009). These types of hazardous and toxic wastes cause enormous harm to the human environment.

The River Kabul, which is among the most important water resources of Pakistan, originates in the Paghman Mountains of Afghanistan and enters Pakistan through Khyber Agency and flows to Warsak Dam. It is the major source of drinking and irrigation water, and recreation. Downstream of the Warsak Dam it divides into three branches: the Shah Alam River, Naguman River and Adezai River. These rivers rejoin into one stream after traveling separately in three branches for about $30 \mathrm{~km}$ and at last unite with the Indus River in Attock District. In the $90 \mathrm{~km}$ stretch from Warsak to Khairabad Kund (Attock) 
different streams and Nallahs unite with the Kabul River and its tributaries. They include Bundi Nallah and Bara River, both carrying municipal sewage and wastewater from Peshawar District; and the Kalpani Nallah that takes wastewater and industrial effluents from different parts of Mardan and Risalpur area (UNEP/GEMS 1995). All these Nallahs discharge the highly polluted wastes directly into the River Kabul without any proper treatment. Therefore, this study was designed to evaluate the potential hazardous associated with the untreated effluent being discharged from some of the main industrial units on the River Kabul water quality. The main objectives of this study were to estimate the wastewater characteristics of some major industrial units like sugar mills, paper mills, ghee mills and textile mills, etc., in the locality of River Kabul and their impacts on the Dissolved Oxygen (DO) and Total Suspended Solids (TSS) concentrations in the River Kabul.

\section{Material and Methodology}

Composite and representative samples were collected from the major sugar, paper, ghee and textile mills, which are discharging their effluent directly or indirectly in the River Kabul. These samples were analyzed for important physical and chemical parameters of wastewater using standard method (APHA/AWWA/WEF 1998).

Composite sampling for more than 6-8months was done at three different locations of the River Kabul, i.e. at a point near to Warsak Dam, at Nowshera on the upstream and downstream of industrial effluent disposal. The main parameters that were tested in these samples are the DO and TSS. Similarly, various representative samples were collected from the industrial units within the scope, i.e. textile mill, paper mill, ghee mill and sugar mill, to properly analyzed the wastewater characteristics of these industrial units.

\section{Results and Discussion \\ Wastewater characteristics of the industrial effluent}

The following Figures 1.0 to 6.o illustrate the wastewater characteristics of the sugar, paper, ghee and textile mills, respectively. The outcome on wastewater characteristic illustrates that the majority of the mills are discharging

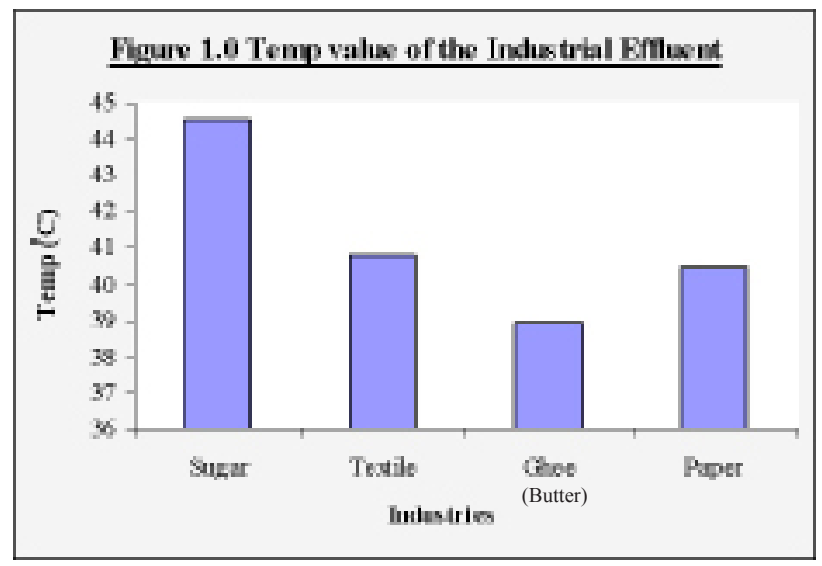

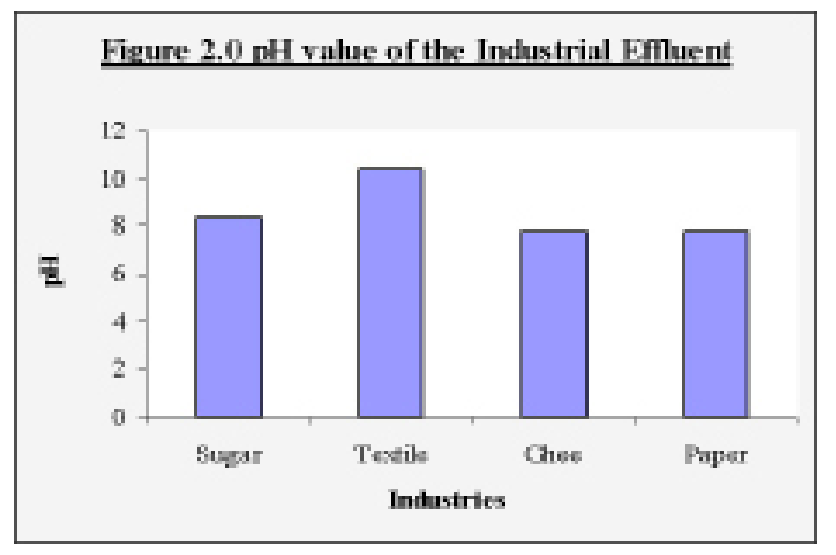
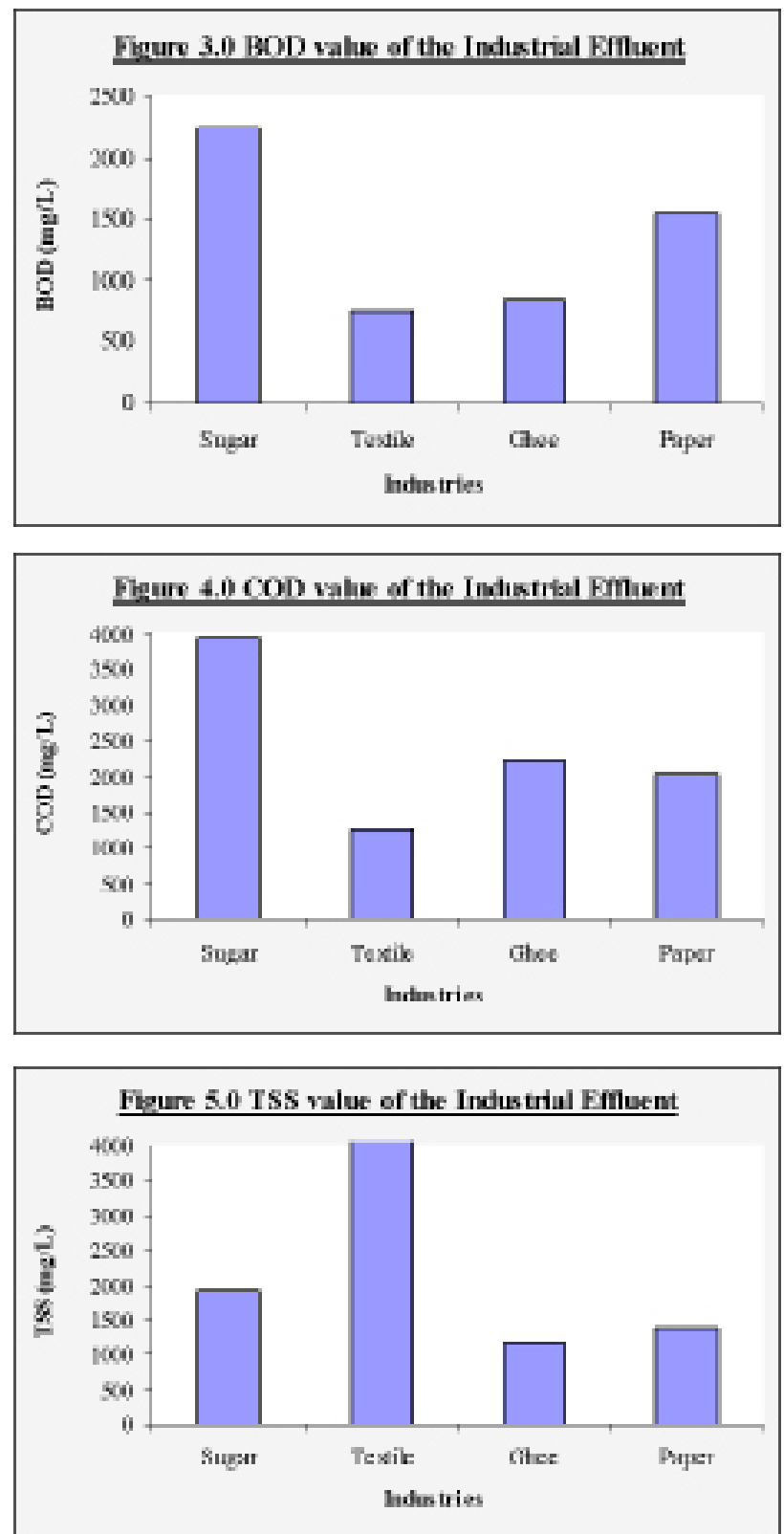

the effluent ahead of the limits laid down by the local legislative guidelines (NEQS, National Environmental Quality Standards). The limits set by Pak-EPA NEQS for the discharge of industrial and domestic effluents in terms of $\mathrm{pH}$, temp, BOD, COD, TSS, and TDS are 


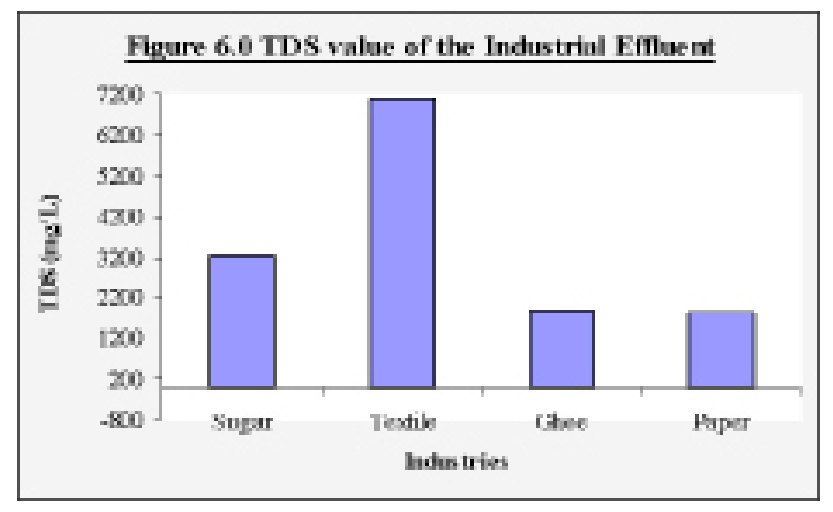

6.0 to $10.0,<400 \mathrm{C}, 80 \mathrm{mg} / \mathrm{L}, 150 \mathrm{mg} / \mathrm{L}, 150 \mathrm{mg} / \mathrm{L}$ and $3500 \mathrm{mg} / \mathrm{L}$ respectively. The physical parameters like temperature and $\mathrm{pH}$, however, show positive results within the standards; nonetheless, the temperature of sugar mills (44.50C) and $\mathrm{pH}$ of the textile mills exceed the limits. These mills are mainly producing high pollutant wastes; i.e., those having high COD and BOD concentrations. The BOD of sugar, paper, ghee and textile mills was observed to be $2235 \mathrm{mg} / \mathrm{L}, 115 \mathrm{omg} / \mathrm{L}$, $844 \mathrm{mg} / \mathrm{L}$ and $745 \mathrm{mg} / \mathrm{L}$ respectively. While, the COD of sugar, paper, ghee and textile mills was noticed as $3945 \mathrm{mg} / \mathrm{L}, 2045 \mathrm{mg} / \mathrm{L}, 224 \mathrm{omg} / \mathrm{L}$ and $1244 \mathrm{mg} / \mathrm{L}$ respectively. The additional key effluent parameters like, TSS and TDS of these mills were also found to be beyond the guidelines established for waste disposal.

\section{Water quality of River Kabul}

The water quality analysis of the River Kabul at three different locations, namely (a) at a distance of about $2.5 \mathrm{~km}$ downstream of Warsak Dam, (b) upstream side of Nowshera District (about $6 \mathrm{~km}$ before the point of industrial effluent discharge), and (c) downstream of Nowshera District (about $5 \mathrm{~km}$ after the point of disposal of industrial and domestic effluent), was analyzed. It indicates that there was an abrupt decrease in the DO concentration and an increase in the TSS concentration between these locations. The concentration of DO and TSS at the three locations, i.e., 'a', 'b' and 'c', were observed as $8.8 \mathrm{mg} / \mathrm{L}, 8.1 \mathrm{mg} / \mathrm{L}$ and $6.7 \mathrm{mg} / \mathrm{L}$, respectively; whereas the concentrations of TSS at these three locations were noticed to be $96 \mathrm{mg} / \mathrm{L}, 204 \mathrm{mg} / \mathrm{L}$ and $382 \mathrm{mg} / \mathrm{L}$, respectively. The results are illustrated in Figures 7.0 and 8.o.

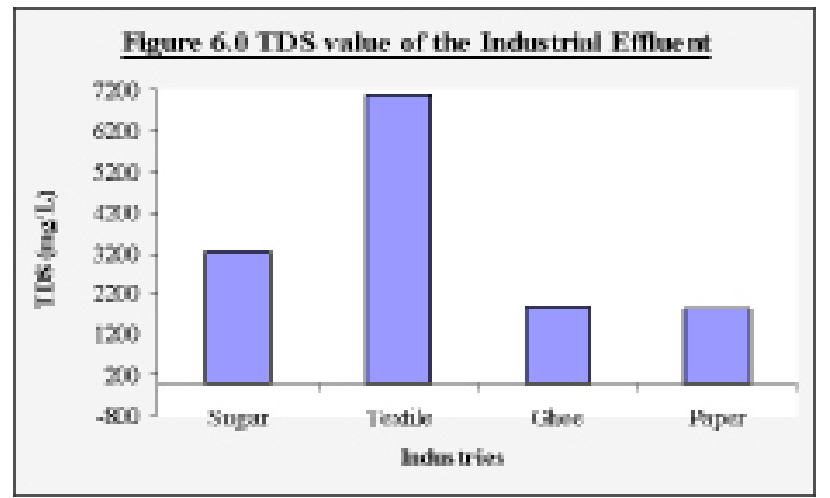

Nature has gifted maximum turbulence to River Kabul while passing through a long strength of about 90 $\mathrm{km}$, which is playing a vital role in the self-purification system of it. A previous study by Durrani (1996) shows similar observations, indicating that the river is achieving greater chances of self-purification, thus it improves its DO at many points after its depletion due to the disposal of untreated, mostly high-strength, industrial effluent in it.

However, most anxiety observed during this study was the alarming loss of the aquatic life in the river. At the point of industrial effluent disposal, nuisance and

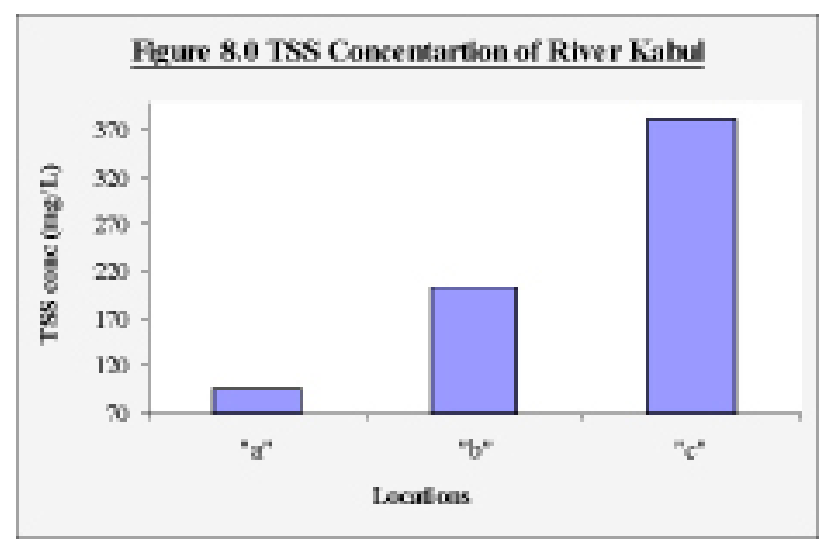

odor was also noticed, which was producing fairly miserable living conditions for the adjacent dwellings. The River Kabul is considered to be one of the most important sources of drinking water, irrigation and aqua-culture, etc. However, it also plays a key role in the spread of water borne diseases due to the disposal of such untreated polluted wastes and wast water. In some parts, it is seen that the river is eroding its edges (banks), which also contributes to an increase in the river TSS concentration.

\section{Conclusion and Recommendations}

The following conclusions have been drawn from the study:

- River Kabul is the prime source of water supply for domestic use, irrigation and industrial use of the surrounding area.

- The river has an excellent capacity of self-purification due to excessive turbulence.

- The water quality of River Kabul itself provides quite favorable conditions for the aquatic life, due to its natural DO concentration of $8.8 \mathrm{mg} / \mathrm{L}$ and negligible concentration of TSS of $96 \mathrm{mg} / \mathrm{L}$.

- The major polluting effluent dispose into River Kabul comes from sugar mills, paper mills, ghee mills and textile mills.

- The wastewater quality analysis indicates that the BOD of sugar, paper, ghee and textile mills was observed to be $2235 \mathrm{mg} / \mathrm{L}, 1150 \mathrm{mg} / \mathrm{L}, 844 \mathrm{mg} / \mathrm{L}$ and $745 \mathrm{mg} / \mathrm{L}$ respectively. Whereas, the COD of sugar, 
paper, ghee and textile mills was noticed to be $3945 \mathrm{mg} / \mathrm{L}, 2045 \mathrm{mg} / \mathrm{L}, 2240 \mathrm{mg} / \mathrm{L}$ and $1244 \mathrm{mg} / \mathrm{L}$ respectively.

- The River Kabul shows abrupt increase in TSS from 96 to $382 \mathrm{mg} / \mathrm{L}$, and high decrease in its DO concentration from $8.8 \mathrm{mg} / \mathrm{L}$ to $6.7 \mathrm{mg} / \mathrm{L}$.

- All the wastewater coming from the industrial sources should be properly treated as an integral part of its production system before disposing them into the river.

A long-term comprehensive study is required to study the effects of these pollutants on the aquatic life within the system, and to draw a detail oxygen-sag curve for the DO concentration of the River Kabul to study in depth its self-purification capacity. Moreover, further study is required to determine other potential pollution sources of River Kabul.

Ghazala Nosheen has done her Masters in Chemistry from the University of Peshawar Pakistan and is serving as Faculty Member at Fazia Degree College Risalpur. She is currently enrolled at the Northern University Nowshera as a potential research scholar of Environmental Sciences. She has numerous research and teaching experience, especially in the field of environmental sciences.

Correspondingaddress:nosheenarshad78@yahoo.com

Prof. Muhammad Ullah, $\boldsymbol{P h D}$, is a renowned Environmental Scientist. He has a versatile and more than 30 years of rich experience in the field of Agricultural and Environmental Sciences by working in many organizations and institutions of an international repute within the country and abroad. Presently, he is serving as Rector in the Northern University Nowshera.

Engr. Kashif Ahmad Khan is a Graduate Civil Engineer with Masters in Transportation Engineering. He has more than 25 years of professional experiences of various projects of civil and environmental engineering. He is currently serving as Senior Instructor in the College of Civil Engineering (MCE-NUST) Risalpur.
Engr. Attiq Ur Rehman is a Graduate Civil Engineer. He has more than 20 years of professional experiences of various projects of civil and environmental engineering. He is currently serving as the Department Head, Disaster Management, in the College of Civil Engineering (MCE-NUST) Risalpur. He is also actively involved in writing research article for several national and international journals, and is currently pursuing his Masters in Engineering Management and GIS from LUND University, Sweden.

\section{Acknowledgement}

The authors would like to thanks Engr. Arshad Ali, Lecturer (MCE-NUST), for his kind technical assistance in carrying out this project, and for his valuable suggestions during the course of study.

\section{References}

APHA/AWWA/WEF, 1998, Standard Methods for the Examination of Water and Wastewater (20th ed.), Washington DC: American Public Health Association.

Ali, A., H.N. Hashmi, I.A. Querashi and S. Athar, 2009, 'Treatment feasibility of NSSC pulping effluent using UASB reactor,' HYDRO Nepal: Journal of Water, Energy and Environment (Kathmandu) 5:5760.

Pak-EPA, 1999, Environmental Technology Programme for Industries (Draft Environmental Report), Islamabad: Environmental Protection Agency, Pakistan.

Steel, E.W., 1995, Water Supply and Sewerage (6th ed.), London: McGraw Hill.

UNEP/GEMS, 1995, Water Quality of World River Basins, Nairobi: UN Environment Program, Global Environment Monitoring System.

Durrani, Jehangir, 1996, Water Pollution in River Kabul (Undergraduate Civil Engineering Project), NWFP University of Engineering and Technology, Peshawar, Pakistan.

Panayotou, Theodore, 1994, Economic Instruments for Environmental Management and Sustainable Development, UNEP Environmental Economics Series Paper No.16, Nairobi: UN Environment Program, Environment and Economics Unit.

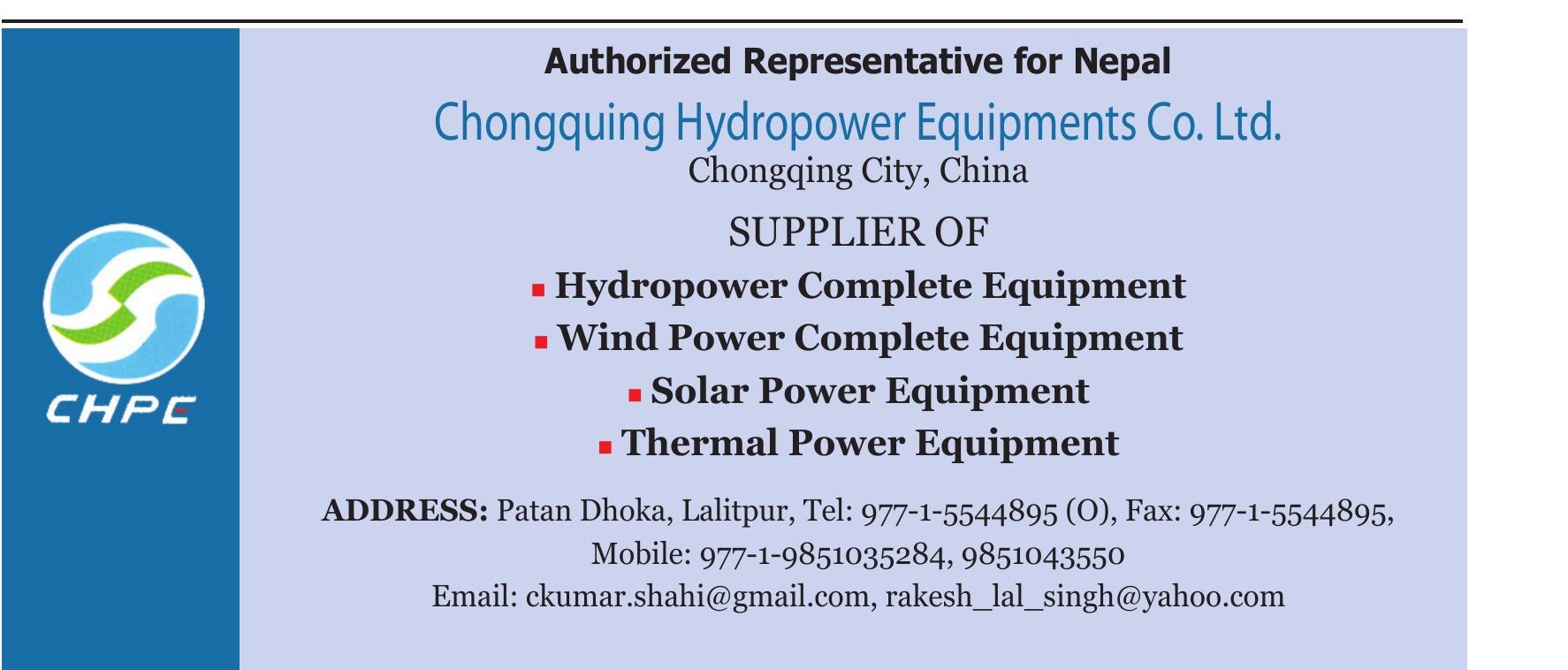

